\title{
垂直加熱平行平板の自然対流と強制対流が 共存する流れの層流熱伝達
}

\author{
暖房用放熱器対流伝熱面の基整的研究 その 2
}

正会員水 野 宏 道*

\section{1. 嘴 言}

前報で平行平板が暖房用放熱器の基本的伝熱面である ことを概説し，その層流自然対流熱伝達に関する実験結 素の考察をした。本報は続報とし自然対流と強制対流が 共存する層流熱伝達の数值解析と結果を報告する。

加熱平行平板を静止空気中に立てると，熱伝達のため 密度差が生じ自然対流により空気が平板間を流動する。 対流空気の圧力（静圧） $p$ と同一高さの外部圧力 $p_{x}$ の 圧力差 $\left(p-p_{x}\right)$ は流机に沿って図一1(a) のごとく変 化し, 板の上端と下端で 0 となる。点線で示すケーシン グを用いると王力差は（b）のように変化し，ケーシン グ上端にグリルを付けるとその通風抵抗 $\Delta p_{g}$ により (c) に示すようになる。さらに下端で強制通風力 $\Delta p_{s}$ が加 えられ, 浮力効果が共存する場合は (d) の上うな変化 となる。

純粋な自然対流熱伝達は伝熱面の通風力と通風抵抗が 平衡した流れ（a）で得られる。（b），(c) は機械通風 力に依存しない意味で自然対流と呼ばれるが，伝熱場の 王力曲線の形 (変化率) が相違し熱伝達は (a) の場合 と異なる゙。

加熱平行平板をグリル付ケーシングで囲うと煙突効果 （通風力）と通風抵抗の相対的大きさにより圧力, 温度, 流れの場が影響を受け熱伝達に差異が生ずる。このよう な場合, 自然対流と強制対流が共存する流れの熱伝達問 題として考察するのが妥当と思われる。

本報で用いた無次元数は前報"と同様, 平板間隔 $b$ を 代表長さとするため流れの状態を判別できない。過去一 連の実験結果 ${ }^{2)}$ より自然対流熱伝達で層流から乱流への 臨界值は $G r_{h} \cdot \operatorname{Pr}=10^{9}$ 付近であり，これを考慮すれば 本問題の遷移点は $R e_{h}=5 \times 10^{5}$ 程度と考えられる。対 流形放熱器のフィン寸法はほぼ $b=2 \sim 10 \mathrm{~mm}, h=50$ 一 $100 \mathrm{~mm}$ の範囲であり, $\bar{u}_{1}=0.05 \sim 1.0 \mathrm{~m} / \mathrm{s}, t_{f}=40 \sim$

*このことは, 運動方程式 (2）の圧力項の形から分かる。

本報告の一部は日本建築学会大会学術講演会（北陸，昭和 58 年 9 月)において発表した。

*工学院大学 助教授・工修

(昭和 58 年 5 月 14 日原稿受理) $100^{\circ} \mathrm{C}, t_{1}=20^{\circ} \mathrm{C}$ の条件により試算すると $R e_{h}=1.0 \times$ $10^{2} \sim 6.0 \times 10^{3}, P e^{*}=0.06 \sim 80, G r^{*} / R e^{* 2}=0.03 \sim$ 110 程度となる。また $h$ が比較的小であるため助走区間 を考慮した熱伝達が必要となる。

以上より対流形放熱器に現れる $P e^{*}, G r^{*} / R e^{\star 2}$ の 範囲を十分考えに入れ層流時の助走区間を含む平均熱伝 達率を考察することとする。

垂直平行平板の自然対流と強制対流が共存する流れの 層流熱伝達問題は平行平板 ${ }^{31,4)}$ のほか, 垂直円管5) -7),

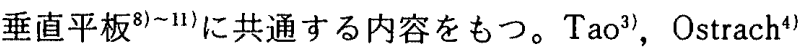
は流れ方向に温度こう配をもつ平行平板の速度発達領域 について近似解析を行い熱伝達の式を得ている。垂直円 管はRosen と Hanratty ${ }^{5)}$, Zeldin と Schmidt ${ }^{6)}$ が等温 加熱面の数値解析を行い, Kemeny と Somers ${ }^{7)}$ が実験 研究による熱伝達を整理し，いずれも浮力効果を $G r_{d} /$ $R e_{d}$ で評価している。垂直平板では浮力効果を $G r_{x}^{1 / 2} /$ $R e_{x}$ で表し局所熱伝達率を整理している。Szewczyk ${ }^{8)}$ は摂動法で第二近似まで解いているが浮力係数の検討範 囲が狭い。鶴野と永井 ${ }^{9)}$ は流れ関数を用いた相似解を J.R. Kliegel の実験值 $(P r=0.72)$ 之対比し $G r_{x} / R e_{x}^{2}$ <1で良好な一致をみている。馬㴊と藤掛 ${ }^{10)}$ は自然対流， 強制対流時の速度, 温度の分布を一次結合し, 基礎方程 式を近似解析することにより広範囲の $G r_{x}^{1 / 2} / R e_{x}$ に適 用可能な熱伝達の簡易式を導いている。

筆者は本問題に対し等温加熱平行平板の助走区間を含

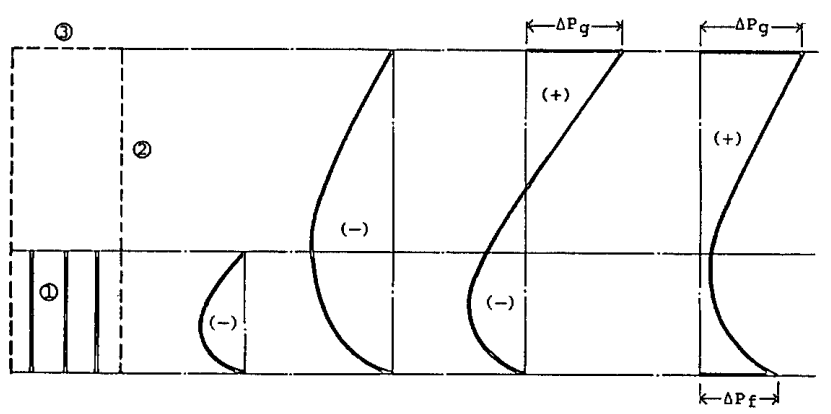

(a)

(b)

Fig. 1 Variation of static pressure difference $\left(p-p_{x}\right)$ at various elevation (1) Heated Plates, (2) Casing, (3) Outlet grille). 
み，広い現象に適用可能で具体的な熱伝達の関係を得る ことを目的とした。基本的には強制対流に浮力が付加さ れる形で流れをとらえ，基礎方程式の無次元化により浮 力効果を変数 $G r^{*} / R e^{* 2}$ で表し，これをパラメータと して平均又セルト数 $N u_{m}$ が変形ペクレ数 $P e^{*}$ で整理で きることを見いだした。その解は数値解析を適用して求 め, 流れと熱伝達の挙動を考察した。

\section{2. 基礎方程式と熱伝達の関係式}

\section{1 基礎方程式}

流れ場を二次元定常状態とし，等温加熱モデルと座標 系を図一2 のごとく定め，空気は非圧縮性，物性値は一 定とする。本問題に影響が無視できる項，他項に比し小 さい項を省略すると境界層の支配方程式は次式で表せ る。

$$
\begin{aligned}
& \frac{\partial u}{\partial x}+\frac{\partial v}{\partial y}=0 \\
& u \frac{\partial u}{\partial x}+v \frac{\partial u}{\partial y}=-\frac{1}{\rho} \frac{\partial\left(p-p_{x}\right)}{\partial x}+\nu \frac{\partial^{2} u}{\partial y^{2}} \\
& +g \beta\left(t-t_{1}\right) \\
& \frac{\partial\left(p-p_{x}\right)}{\partial y}=0 \\
& u \frac{\partial t}{\partial x}+v \frac{\partial t}{\partial y}=a \frac{\partial^{2} t}{\partial y^{2}}
\end{aligned}
$$

$y$ 方向運動方程式 (3) より $\left(p-p_{x}\right)$ は $x$ のみの関 数となる。図一 2 の平板間は $x$ 軸に対称ゆえ解析領域を $0 \leqq x \leqq h, 0 \leqq y \leqq b / 2$ の半区間とする。未知数が $u, v$, $p, t$ に対し, 基礎方程式が（1)，(2)，(4) の 3 式 であるため, 平板間半区間の流量を与える次式を基礎方 程式に加える。

$$
m=\int_{0}^{\frac{b}{2}} u d y
$$

流れと熱伝達を支配する無次元数と関係式を導くため 基礎方程式を無次元化する。このため, 次の無次元変数 を定義する。

$$
\begin{aligned}
& X=\frac{x}{h}, \quad Y=\frac{y}{b}, \quad U=\frac{u}{\bar{u}_{1}}, \quad V=\frac{v}{\bar{u}_{1}}\left(\frac{h}{b}\right) \\
& \Theta=\frac{t-t_{1}}{t_{f}-t_{1}}, \quad P=\frac{p-p_{x}}{\rho \bar{u}_{1}^{2}}
\end{aligned}
$$

また，変形ぺクレ数 $P e^{*}$ を次式で定義する。

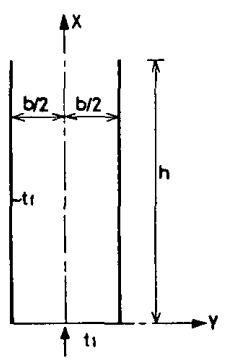

Fig. 2 Parallel plates and coordinates system.

$$
P e^{*}=\frac{\bar{u}_{1} \cdot b}{\nu} \cdot \frac{b}{h} \cdot P r
$$

上式の導入により，基礎方程式（1)，(2)，(4)，(5) は次の無次元連立方程式に变数変換される。

$$
\begin{aligned}
& \frac{\partial U}{\partial X}+\frac{\partial V}{\partial Y}=0 \\
& U \frac{\partial U}{\partial X}+V \frac{\partial U}{\partial Y}=-\frac{\partial P}{\partial X}+\frac{P r}{P e^{*}} \frac{\partial^{2} U}{\partial Y^{2}}+\left(\frac{G r^{*}}{R e^{* 2}}\right) \Theta \\
& U \frac{\partial \Theta}{\partial X}+V \frac{\partial \Theta}{\partial Y}=\frac{1}{P e^{*}} \frac{\partial^{2} \Theta}{\partial Y^{2}} \\
& M=\int_{0}^{\frac{1}{2}} U d Y=\frac{1}{2}
\end{aligned}
$$

解析に適用する境界条件を次のごとく定める。

$$
\begin{aligned}
& X=0, \quad 0 \leqq Y \leqq 1 / 2: \\
& U=U_{1}, \quad V=0, \quad \theta=0, \quad P=0 \\
& Y= 0, \quad 0 \leqq X \leqq 1: \\
& \partial U / \partial Y=0, \quad V=0, \quad \partial \Theta / \partial Y=0 \\
& Y= 1 / 2, \quad 0 \leqq X \leqq 1: \\
& U=0, \quad V=0, \quad \theta=1
\end{aligned}
$$

ここで平板下端 $(X=0)$ の流入速度分布 $U_{1}$ として, 次 式の一様分布と放物線分布を与える。

$$
U_{1}=1 \text { または } 3 / 2\left(1-4 Y^{2}\right)
$$

\section{2 熱伝達の関係式}

平板の任意高さ $x$ における局所熱伝達率を $\alpha_{x}$ とすれ ば $\alpha_{x} \cdot \theta_{f}=\lambda(\partial \theta / \partial y)_{y=\frac{b}{2}}$ により局所又セル卜数 $N u_{x}$ は

$$
N u_{x}=\left(\frac{\partial \Theta}{\partial Y}\right)_{Y=\frac{1}{2}}
$$

連続方程式（7）を用いエネルギ方程式（9）を変形し,

$$
\frac{\partial U \Theta}{\partial X}+\frac{\partial V \Theta}{\partial Y}=\frac{1}{P e^{*}} \frac{\partial^{2} \Theta}{\partial Y^{2}}
$$

上式を $Y=0 \sim 1 / 2$ で積分し，式（13）の関係を用いて 整理すれば次式を得る。

$$
N u_{x}=P e^{*} \frac{\partial}{\partial X} \int_{0}^{\frac{1}{2}} U \Theta d Y
$$

上式を $X=0$ １で積分することにより，平均ヌセルト 数 $N u_{m}$ は次式の形で得られる。

$$
\begin{aligned}
& N u_{m}=\left(\int_{0}^{\frac{1}{2}} U \theta d Y\right]_{x=1} \cdot P e^{*}=Q(1) \cdot P e^{*} \ldots \\
& \text { ここに， } \\
& Q(X)=\left[\int_{0}^{\frac{1}{2}} U \Theta d Y\right]_{X}
\end{aligned}
$$

$Q(X)$ は平板間半区間を上昇する空気が高さ $X$ までに 取得した無次元熱量である。また，高さ $X$ の空気の無 次元平均温度 $\bar{\theta}(X)$ は次式で与えられる。

$$
\bar{\Theta}(X)=\frac{Q(X)}{M}=2 Q(X)
$$

以上を総合することにより，垂直加熱平行平板の自然 対流之強制対流が共存する層流流れ場において，平均又 
セルト数 $N u_{m}$ は変形ペクレ数 $P e^{\text {蕅 }}$ 浮力効果の変数 $G r^{*} / R e^{* 22}$ の関数として整理できる。また，代表長さ $b$ を $h$ に変えると $G r^{*} / R e^{* 2}=G r_{h} / R e_{h}^{2}$ の関係にある ことも分かる。

基礎方程式 (7) （10）は非線形であり解析的に解く のは困難である。よって，特別な場合を除き次章で数值 解析により解くこととする。

2.3 温度, 速度が十分発達した場の熱伝達

発達した温度場のエネルギ方程式は次式に要約され る。

$$
V \frac{d \theta}{d Y}=\frac{1}{P e^{4}} \frac{d^{2} \theta}{d Y^{2}} \equiv 0
$$

これを境界条件（11）により解いて

$$
\theta=1
$$

よって, $Q(1)=M=1 / 2$ となり, 平均ヌセルト数 $N u_{m}$ は

$$
N u_{m}=\frac{1}{2} P e^{4}
$$

で与えられる。さらに, 速度場も発達した場合, $V=0$, $U \equiv U(Y)$ となり，運動方程式は次の形になる。

$$
-\frac{d P}{d X}+\frac{1}{R e^{* t}} \frac{d^{2} U}{d Y^{2}}+\frac{G r^{*}}{R e^{* 2}}=0
$$

$P, U$ はそれぞれ $X, Y$ のみの関数であるから

$$
\frac{d P}{d X}-\frac{G r^{*}}{R e^{* 2}}=-\frac{1}{R e^{*}} \frac{d^{2} U}{d Y^{2}} \equiv C \text { (定数) }
$$

上式を境界条件（11）と流量の式（10）により解けば $C=-12 / R e^{*}$ となり, 速度 $U$, 圧力こう配 $d P / d X$ は 饮式で表せる

$$
\begin{aligned}
& U=\frac{3}{2}\left(1-4 Y^{2}\right) \cdots \\
& \frac{d P}{d X}=\frac{G r^{*}}{R e^{* 2}}-\frac{12}{R e^{*}}
\end{aligned}
$$

式 (25) より発達場の圧力こう配 $d P / d X$ は $G r /$ $R e^{* 2}$ の值により正 (逆圧力こう配)，負いずれにもな り得ることが分かる。

\section{4 速度分布が放物線状の場合の強制対流熱伝達}

速度 Uが式 (24) の放物線状分布（Parabolic velocity profile) で $X$ 方向に変化しないとき, 運動, エネル ギ両式は次式のように要約され，それぞれ独立の式とな る。

$$
\begin{aligned}
& \frac{d P}{d X}=-12 R e^{*-1} \cdots \\
& U \frac{\partial \Theta}{\partial X}=\frac{1}{P e^{* k}} \frac{\partial^{2} \Theta}{\partial Y^{2}}
\end{aligned}
$$

\section{3. 数值解析}

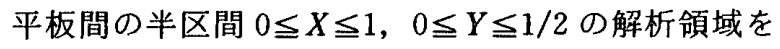
図一 3 に示すように分割する。ここで基礎方程式（7） ～(10) の各式を以下のごとく差分展開する。

$$
\frac{U_{i+1, j+1}+U_{i+1, j}-U_{i, j+1}-U_{i, J}}{2 \Delta X_{i}}-\frac{V_{i+1, j+1}-V_{i+1, j}}{\Delta Y_{j}}=0
$$

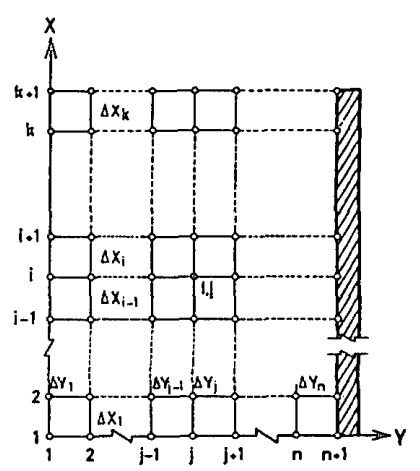

Fig. 3 Mesh network for difference representations.

$$
\begin{aligned}
& U_{i, J} \frac{U_{i+1, j}-U_{i, J}}{\Delta X_{i}}+V_{t, J} \frac{U_{i+1, j+1}-U_{i+1, J-1}}{\Delta Y_{j-1}+\Delta Y_{j}} \\
& =\frac{P r}{P_{e}^{* k}} \cdot \frac{\frac{U_{i+1, J+1}-U_{i+1, J}}{\Delta Y_{J}}-\frac{U_{t+1, j}-U_{i+1, j-1}}{\Delta Y_{j-1}}}{\frac{1}{2}\left(\Delta Y_{j-1}+\Delta Y_{j}\right)} \\
& -\frac{P_{i+1}-P_{i}}{\Delta X_{i}}+\frac{G r^{*}}{R e^{* 2}} \theta_{i+1, j} \\
& U_{i, j} \frac{\theta_{i+1, j}-\Theta_{i, j}}{\Delta X_{i}}+V_{i, j} \frac{\theta_{i+1, j+1}-\theta_{i+1, j-1}}{\Delta Y_{j-1}+\Delta Y_{j}} \\
& =\frac{1}{P_{e}^{+i}} \frac{\frac{\theta_{i+1, j+1}-\Theta_{i+1, j}}{\Delta Y_{j}}-\frac{\Theta_{i+1, j}-\Theta_{i+1, j-1}}{\Delta Y_{j-1}}}{\frac{1}{2}\left(\Delta Y_{J-1}+\Delta Y_{j}\right)}
\end{aligned}
$$

$$
\begin{aligned}
M= & \frac{1}{2}\left[\left(2 \Delta Y_{1}+\Delta Y_{2}\right) U_{t+1,2}\right. \\
& \left.+\sum_{j=3}^{n}\left(\Delta Y_{j-1}+\Delta Y_{j}\right) U_{t+1, j}\right]
\end{aligned}
$$

無次元取得熱量 $Q(X)$, 局所および平均ヌセルト数 $N u_{x}, N u_{m}$ も定義に従い差分化する。

$$
\begin{aligned}
& Q_{l+1}=\frac{1}{2}\left[\left(2 \Delta Y_{1}+\Delta Y_{2}\right) U_{i+1,2} \cdot \Theta_{i+1,2}\right. \\
& \left.+\sum_{j=3}^{n}\left(\Delta Y_{j-1}+\Delta Y_{j}\right) U_{i+1, j} \theta_{i+1, j}\right] \\
& N u_{x_{t+1}}=\frac{1-\Theta_{i+1, n}}{\Delta Y_{n}} \\
& N u_{m}=Q_{k+1} \cdot P e^{*}
\end{aligned}
$$

境界条件として $U_{\mathrm{l}}$ が一様分布の場合を例示すれば

$$
\left.\begin{array}{l}
X=0: U_{1, J}=1, \quad V_{1, J}=0, \quad \theta_{1, J}=0, \quad P_{1}=0 \\
Y=0: U_{i+1,1}=U_{i+1,2}, \quad V_{i+1,1}=0, \quad \theta_{i+1,1}=\theta_{i+1,2} \\
Y=1 / 2: U_{i+1, n+1}=0, \quad V_{i+1, n+1}=0, \quad \theta_{i+1, n+1}=1
\end{array}\right\}
$$

上記差分式のうち運動方程式 (29) の数が $(n-1)$ であるのに対し $U_{i+1, j}$ が $(n-1), P_{i+1}$ が 1 で末知数の 合計が $n$ となる。これを補うため式 (31) を同時に用 いる。

差分方程式の具体的解法は $i$ レベルの既知量を用い, $i+1$ レベルの未知量を前進的に計算するものである。 
まず，エネルギ式 (30) を解いて $i+1$ レベルの $\boldsymbol{\theta}_{i+1, j}$ を求め, 次いで式 $(29),(31)$ より $U_{t+1, N}, P_{t+1}$ を求め, 式 (28) より $V_{i+1, J}$ を算出する。この操作を $i=1$ から $i=k$ まで順次実行し, 全解析領域内の $U_{i+1, j+1}, V_{i+1, j+1}$, $\theta_{i+1, j+1}, P_{i+1}$ を求め, 各レベルの $Q_{i+1}, \bar{\theta}_{i+1}, N u_{x_{t+1}}$
を決定し， $Q_{k+1}$ をもって $N u_{m}$ を求める。あらかじめ計 画した $P e^{*}, G r^{*} / R e^{* 2}$ の値の組み合わせに対し以上 を繰り返し実行した。式 (26)，(27）も同様の方法で差 分化し, $P e^{*}$ に対する $\theta_{t+1, j+1}, P_{i+1}$ を求めた。なお, 空気のプラントル数 $\operatorname{Pr}$ は 0.71 とし演算では式 (29) 〜（31）を次式の形で用いた。

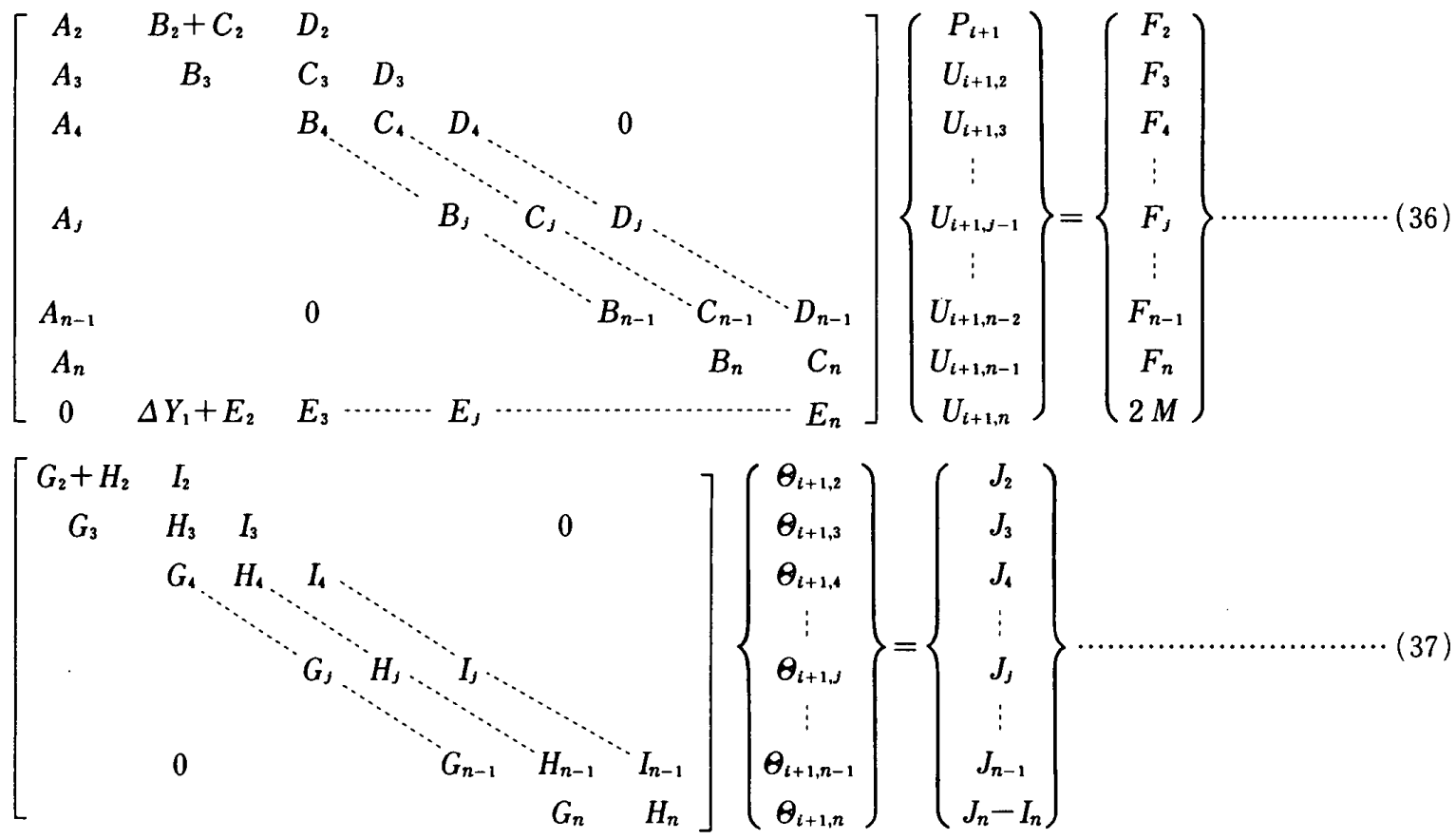

ここに,

$$
\begin{aligned}
& A_{j}=\frac{1}{\Delta X_{i}} \\
& B_{j}=\frac{-V_{t,}}{\Delta Y_{j-1}+\Delta Y_{j}}-2 \frac{P r}{P e^{*}} \frac{1}{\Delta Y_{j-1}\left(\Delta Y_{j-1}+\Delta Y_{j}\right)} \\
& C_{j}=\frac{U_{i j}}{\Delta X_{i}}+2 \frac{P r}{P e^{*}} \frac{1}{\Delta Y_{j-1} \cdot \Delta Y_{j}} \\
& D_{j}=\frac{V_{l j}}{\Delta Y_{j-1}+\Delta Y_{j}}-2 \frac{P r}{P e^{*}} \frac{1}{\Delta Y_{j}\left(\Delta Y_{j-1}+\Delta Y_{j}\right)} \\
& E_{J}=\Delta Y_{j-1}+\Delta Y_{j}
\end{aligned}
$$

この差分法は $X$ 方向を前進差分， $Y$ 方向を中心差分

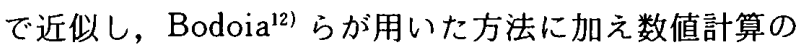
精度を高めるため, $P e^{*}$ および $G r^{*} / R e^{* 2}$ の範囲に応 じて分割数の増減を行うとともに, 流れの変化が大きい 板面近傍と平板下部付近で格子間隔 $\Delta X_{i}, \Delta Y_{j}$ が細か くなるよう配慮した婲。

\section{4. 数值解析の結果と考察}

\section{1 計算結果と考察}

図-4 は平板上端の平均空気温度 $\bar{\theta}(1)\left\llcorner P e^{*}\right.$ の関 係であり，Gr*/R $e^{* 2}$ とともに $\bar{\theta}(1)$ は高くなる。解 析值によれば $P e^{*} \leqq 1.5$ の低 $P e^{*}$ 領域で $\overline{\boldsymbol{\theta}}(1) \geqq 0.99$ となり温度場は発達する。

図一 5 は速度 $U, V$, 温度 $\theta$, 取得熱量 $Q$, 圧力 $P$, 局所ヌセルト数 $N u_{x}$ の $X$ 方向変化を $P e^{*}=10$,
$F_{j}=\frac{U_{l, j} \cdot U_{t, j}+P_{\ell}}{\Delta X_{i}}+\frac{G r^{*}}{R e^{* 2}} \theta_{i+1, j}$

$G_{j}=-\frac{V_{i,}}{\Delta Y_{j-1}+\Delta Y_{j}}-2 \frac{1}{P e^{*}} \frac{1}{\Delta Y_{j-1}\left(\Delta Y_{j-1}+\Delta Y_{j}\right)}$

$H_{J}=\frac{U_{t J}}{\Delta X_{i}}+2 \frac{1}{P e^{*}} \frac{1}{\Delta Y_{J-1} \cdot \Delta Y_{J}}$

$I_{j}=\frac{V_{i, j}}{\Delta Y_{J-1}+\Delta Y_{j}}-2 \frac{1}{P e^{*}} \frac{1}{\Delta Y_{j}\left(\Delta Y_{j-1}+\Delta Y_{j}\right)}$

$J_{j}=\frac{U_{i, j} \cdot \theta_{i, j}}{\Delta X_{i}}$

$G r^{*} / R e^{* 2}=0$ (実線) および $G r^{*} / R e^{* 2}=10$ (破線) につき例示した。

$G r^{*} / R e^{* 2}=0$ (強制対流) のとき平板間下部で $V$ の

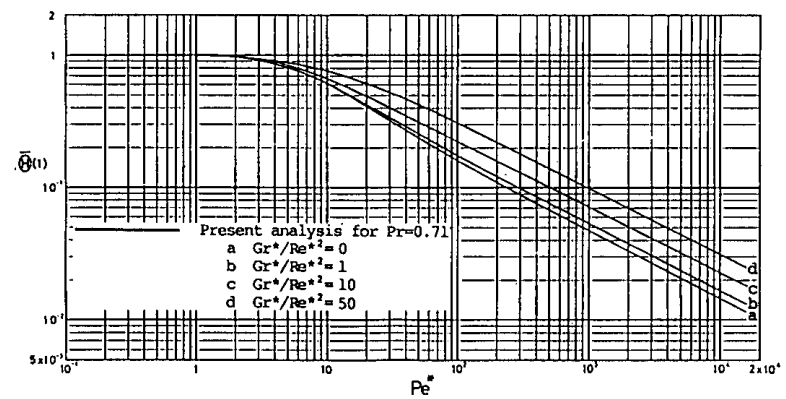

Fig. 4 Variation of mean air temperature $\bar{\theta}$ at the top of plates versus modified Peclet number $P e^{*}$. 


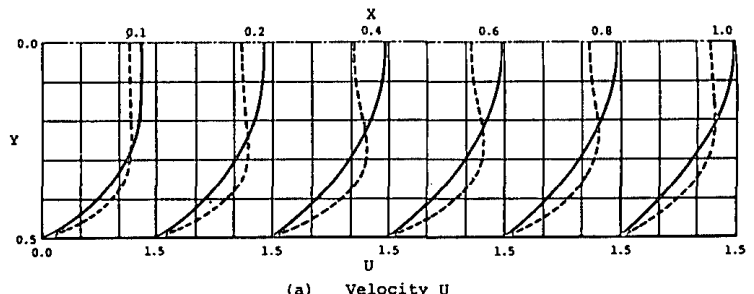

(a) velocity U

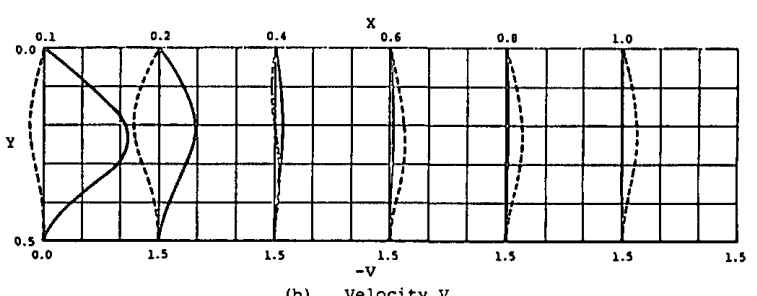

(b) Velocity $\mathrm{v}$

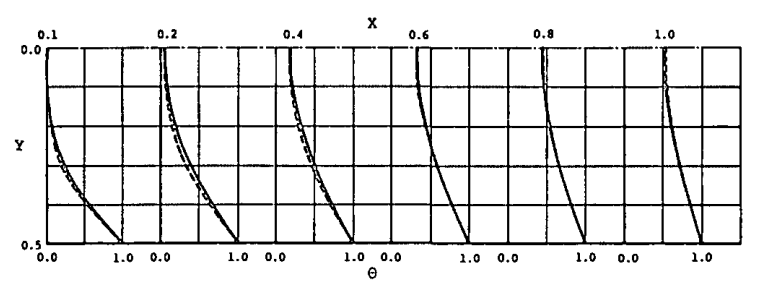

(c) Temperature $\theta$

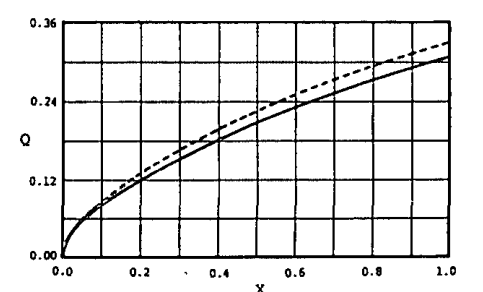

(d) Heat flux $Q$

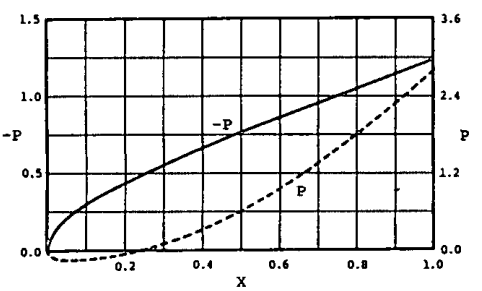

(e) Pressure $P$

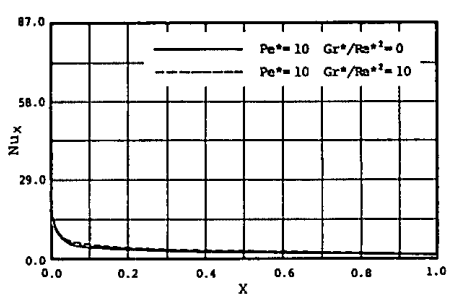

(f) Local Nusselt number $\mathrm{Nu}_{\mathrm{x}}$

Fig. 5 Variation of $U, V, \theta, Q, P$ and $N u_{x}$ versus elevation in channel $X\left(P e^{*}=10, G r^{*} / R e^{* 2}=0\right.$ and 10$)$.

変化が大きく中心に向かっている。 $U$ は $X$ の中央で放 物線に近い分布となり，P は常に負で変化は下端付近 で大きい。core 内の流れに運動方程式を適用すれば近 似的に $1 / 2\left(\partial U^{2} / \partial x\right)+(d P / d X)=0$ が成り立ち, $P$ の 変化が大きい下部で $U$ の変化も大となることが分かる。 $U$ は上方で放物線状分布となるが，Q， $\otimes$ の変化は未 発達であることを示している。

$G r^{*} / R e^{* 2}=10$ のとき $P$ は下部で一時負となり，以 降は正圧となる。Vは下部で板面へ向かって流れ，上 部で中心へ向う流れとなる。 $U$ は浮力の影響により， 中央で板寄りに最大値をもつ分布となるが，上部では中 心に向かう $V$ の流れとともに消える。流れの混合作用 のため, $G r^{*} / R e^{* 2}=0$ に比較し $Q, N u_{x}$ ともに大であ $\eta$ ，平均熱伝達率 $\boldsymbol{\alpha}_{m}$ は高くなるものと思われる。

図一6は $N u_{m}$ と $P e^{*}$ を両軸にとり，変数 $G r^{*} / R e^{* 2}$ をパラメータとして熱伝達の関係を示した。平均熱伝達 率 $\alpha_{m}$ は $G r^{*} / R e^{* 2}$ とともに増大する。図中には数値解 析で得た数値の一部を参考として表記した。(a) は平板 下端の境界条件 $U_{1}=1$ の場合，(b) は $U_{1}=3 / 2\left(1-4 Y^{2}\right)$ の場合である。流入部境界条件である速度分布の相違は 平均熱伝達率 $\alpha_{m}$ に大きく影響するが，同時に計算した 動圧增加に伴う静圧降下を考慮した圧力条件による解と の差は微小で演算誤差範囲の程度であった。

図一6 の結果は 2 章および図一 4,5 の考察とも一致し, $N u_{m}$ は低 $P e^{*}$ 領域で $G r^{*} / R e^{* 2}$ に関係なく発達場の 式（21）に漸近する。 $G r^{*} / R e^{* 2}=100,10<P e^{*}<100$
の範囲は本数値解析で妥当な解が得られず，図中では破 線により示した。逆王力こう配のとき流れは不安定な状 態となり, 境界層のはく離などの問題を伴う。低 $P e^{\text {» }}$ 領域は粘性流れに近く，運動方程式の慣性項による影響

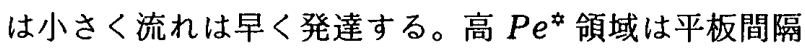
$b$ が大なる場合と等価になり垂直平板に沿う流れに帰着 するため, 圧力 $P$ の值が微小となり逆圧力こう配の影 響は無視できる。以上より，Gr$r^{*} / R e^{* 2}$ が大のとき流 れの不安定領域はほぼ $10<P e^{*}<10^{2}$ の中間領域と考え られる。

図 (a) の解曲線は高 $P e^{*}$ 領域ですべてこう配 $1 / 2$ の 直線に漸近し垂直平板の特性に近づく。(b) では $G r^{*} /$ $R e^{* 2}$ が大のとき $1 / 2, G r^{*} / R e^{* 2}=0$ のとき $1 / 3$ のこう 配をもつ直線に漸近する。

\section{2 結果の比較と関数近似}

境界条件 $U_{1}=1$ による数値解を近似し次式を得た。

$$
\begin{aligned}
& N u_{m}=\frac{1}{2} P e^{*}\left[1-\exp \left\{-\left(\frac{C_{1}}{P e^{*}}\right)^{c_{2}}\right\}\right]^{c_{3}} \\
& \cdot\left[1-\exp \left(-\frac{C_{4}}{P e^{m}}\right)\right]^{-0.245}
\end{aligned}
$$

ここに, $B=\frac{G r^{*}}{R e^{4.2}}, C_{1}=(4.5+0.012 B)^{\frac{4}{3}}$,

$$
C_{2}=1-0.002 B, C_{3}=\frac{3}{4} C_{2}^{-1}
$$

$$
\begin{aligned}
C_{4}= & \left(\frac{2.25+0.006 B}{0.76+0.106 B^{0.821}\left\{1-\exp \left(-\frac{3.37}{B}\right)\right\}^{0.41}}\right)^{0.245} \\
& \left(0 \leqq G r^{*} / R e^{3.22} \leqq 50,0.1 \leqq P e \leqq 2 \times 10^{4}\right)
\end{aligned}
$$



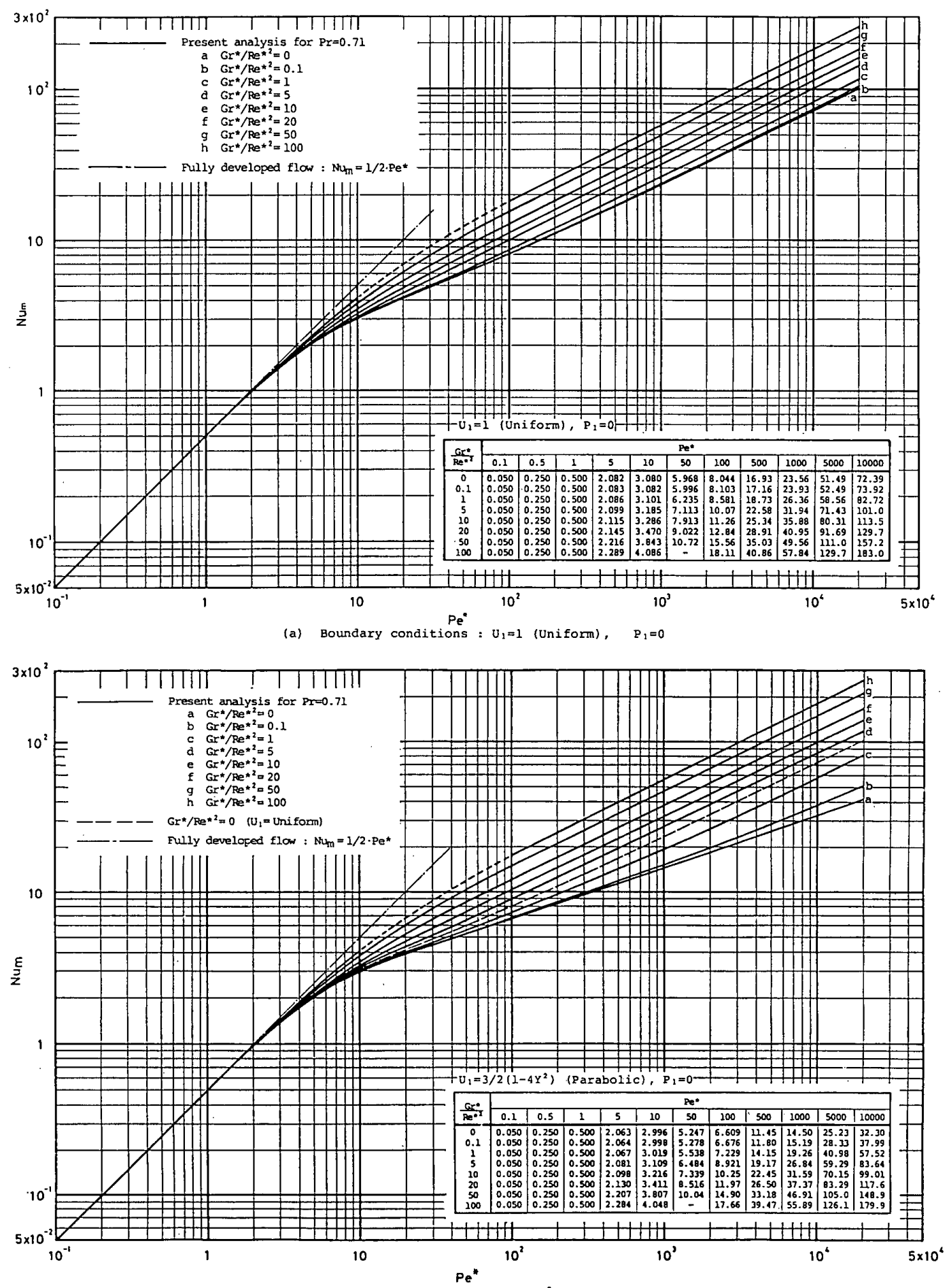

(b) Boundary conditions : $\mathrm{U}_{1}=3 / 2\left(1-4 \mathrm{Y}^{2}\right)$ (Parabolic), $\quad \mathrm{P}_{1}=0$

Fig. 6 Variation of mean Nusselt number $N u_{m}$ versus modified Peclet number $P e^{*}$ for parallel plates in laminar combined forced and free convection.

$G r^{*} / R e^{* 2}=100$ については $10<P e^{*}<10^{2}$ の数値が無 いため近似領域より除外した。上式は近似誤差 $2.9 \%$ 以内で数值解を満足する。強制対流時は $G r^{*} / R e^{* 2} \rightarrow 0$ とし次式を得る。

$$
\begin{aligned}
N u_{m}= & \frac{1}{2} P e^{*}\left[1-\exp \left\{-\left(\frac{7.43}{P e^{*}}\right)\right\}\right]^{0.75} \\
& \cdot\left\{1-\exp \left(-\frac{77.11}{P e^{*}}\right)\right\}^{-0.24} \ldots \ldots \ldots \ldots
\end{aligned}
$$

\section{$\left(0.1 \leqq P e^{*} \leqq 2 \times 10^{4}\right)$}

数值解に対する上式の近似誤差は $0.94 \%$ 以内である。 図一6で $G r^{*} / R e^{* 2}$ が小のとき, 平均熱伝達率 $\alpha_{m}$ の 極大值が $P e^{*}=10$ 付近に現れる。式 (39) による $\alpha_{m}$ の極大值は $\partial \alpha_{m} / \partial b=0$ より $P e^{*}=9.77$ で，このとき $N u_{m}=3.05$ となる。解析値を用いた $b / h$ に対する $\alpha_{m} / \alpha_{m \infty}$ の変化は図一7に条件とともに示した。 $\alpha_{m \infty}$ は $P e^{*}=2 \times 10^{4}$ の値であり, 物性値の評価温度は $t_{s}$ とし 


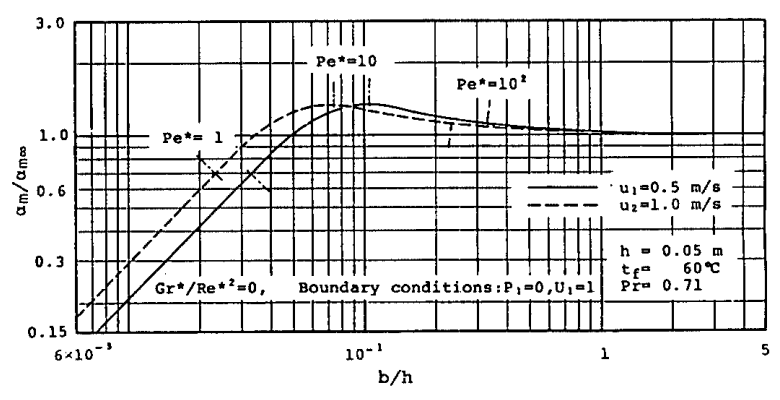

Fig. 7 Variation of $a_{m} / \alpha_{\text {mos }}$ versus $b / h$.

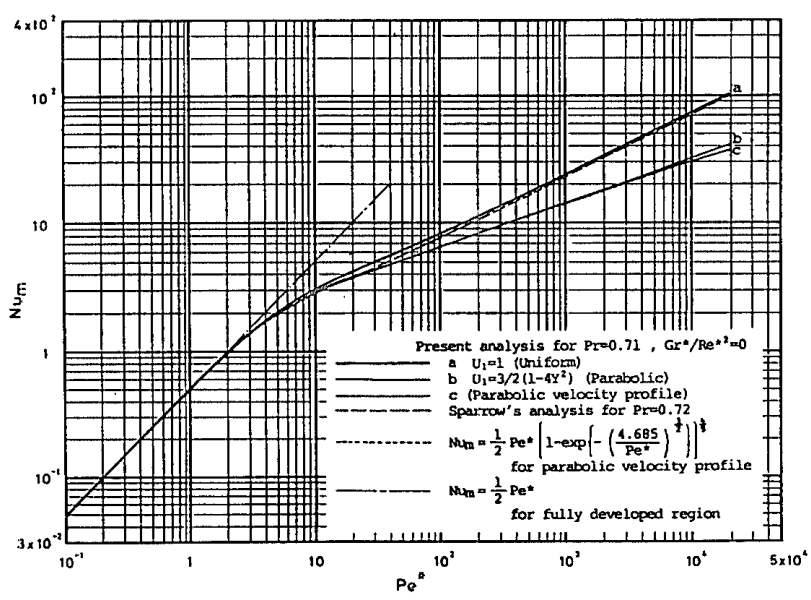

Fig. 8 Variation of mean Nusselt number $N u_{\mathrm{m}}$ versus modified Peclet number $P e^{*}$ for parallel plates in laminar forced convection, and comparison of this analysis and the work of Sparrow.

た。 $\alpha_{m}$ のピークが図中で明らかに認められる。

強制対流時の比較は図一8に示す。曲線 $a$ は $U_{1}=1$ の解で, 同一境界条件による Sparrow ${ }^{13)}$ の結果に比し $P e^{*}=20$ で約 $7.7 \%$ 高い $N u_{m}$ を与える。この差異は 13）が速度と温度の分布をそれぞれの境界層厚さを用い 多項式近似し， core 内の流速を $Y$ 方向に一様と仮定し

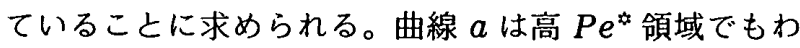
ずかな曲線性を示すが近似式を $N u_{m}=C \cdot P e^{\not 1 / 2}$ とし $P e^{*}=5 \times 10^{3}, 10^{4}$ の数值解より定数 $C$ はそれぞれ $0.728 ， 0.724$ と求まる。後者の值を用い $N u_{m}$ と $P e^{\star x}$ の代表長さ $b$ を $h$ に変えても式の形は保存され次式を 得る。

$$
N u_{m h}=0.724\left(R e_{h} \cdot \operatorname{Pr}\right)^{\frac{1}{2}}
$$

上式は Pohlhausen ${ }^{14)}$ の解と比較し約 $3.7 \%$ 高い $N u_{m h}$ を与える。

曲線 $b$ は境界条件 $U_{1}=3 / 2\left(1-4 Y^{2}\right)$ の解, 曲線 $c$ は速度分布 $U=3 / 2\left(1-4 Y^{2}\right)$ が変化しないと仮定した 解である。曲線 $c$ は同一条件による Sparrow ${ }^{13)}$ の解と 良好な一致をみた。曲線 $b, c$ の差異は $P e^{*}=10$ 付近 と $P e^{\text {* }}>3 \times 10^{2}$ の両領域に認められ，いずれも曲線 $b$ が高い $N u_{m}$ を与える。

解曲線 $b, c$ の熱伝達はそれぞれ次式で近似できた。

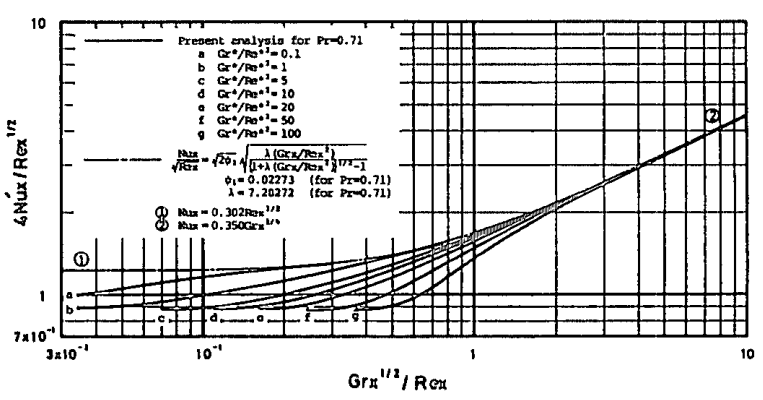

Fig. 9 Variation of $4 N u_{x}^{\prime} / R e_{x}^{1 / 2}$ as a function of $G r_{x}^{1 / 2} / R e_{x}$ for vertical plate in laminar combined forced and free convection, and comparison of this analysis and a result of Mabuchi.

$$
\begin{aligned}
N u_{m}= & \frac{1}{2} P e^{*}\left[1-\exp \left\{-\left(\frac{7.678}{P e^{*}}\right)\right\}\right]^{0.82} \\
& \cdot\left(1-\exp \left\{-\left(\frac{73.9}{P e^{*}}\right)\right\}\right]^{-0.17} \cdots \cdots \cdots . . . \\
N u_{m}= & \frac{1}{2} P e^{*}\left(1-\exp \left\{-\left(\frac{4.685}{P e^{*}}\right)^{\frac{3}{2}}\right)\right]^{\frac{4}{9}} . \\
& \left(0.1 \leqq P e^{*} \leqq 2 \times 10^{4}\right)
\end{aligned}
$$

上式はそれぞれ最大諤差 $1.0 \%, 2.1 \%$ で数值解を満足 し， $\alpha_{m}$ の極大值は $P e^{*}=8.36,6.98$ で生じ，このとき

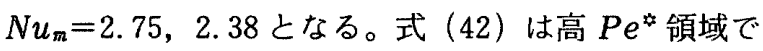

$$
N u_{m}=1.4 P e^{\frac{1}{3}} \text {. }
$$

に漸近し，Norris ら ${ }^{15)}$ の flat duct に対する近似式 $\left(P e^{*} \geqq 100\right)$ に比較し約 $4.9 \%$ 低い平均熱伝達率を与 える。

自然対流と強制対流が共存する場合の比較は平行平板 に条件の合う報告例が見当らないので垂直平板と試み る。その局所熱伝達率は無次元数 $N u_{x}^{\prime} / R e_{x}^{1 / 2}$ と $G r_{x}^{1 / 2} / R e_{x}$ で整理されており，次の関係がある。

$$
\frac{N u_{x}^{\prime}}{R e_{x}^{1 / 2}}=\frac{N u_{x}}{R e^{* 1 / 2}} \cdot X^{\frac{1}{2}}, \frac{G r_{x}^{1 / 2}}{R e_{x}}=\frac{G r^{* 1 / 2}}{R e^{* t}} \cdot X^{\frac{1}{2}}
$$

本報は平均熱伝達率を目的としており，Pe $G r^{* 1 / 2} / R e^{*}$ には $x=h(X=1)$ を用いている。このと き上式は

$$
\frac{N u_{h}^{\prime}}{R e_{h}^{1 / 2}}=\frac{N u_{h}}{R e^{* 1 / 2}}, \frac{G r_{h}^{1 / 2}}{R e_{h}}=\frac{G r^{* 1 / 2}}{R e^{* h}}
$$

となる。図一9は馬㴊ら ${ }^{10)}$ の近似解を引用し, $U_{1}=1$, $P e^{*}=10^{4}, G r^{*} / R e^{* 2}=0.1 \sim 100$ の結果を用い, $0 \leqq X \leqq 1$ に対する $N u_{x}$ により式 (44) の関係を示した。

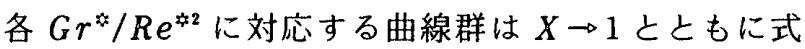

(45) の関係に収束し良好な一致を示す。

\section{5. 结 論}

助走区間を含む等温加熱垂直平行平板の自然対流と強 制対流が共存する層流熱伝達を二次元定常流れ場で数值 解析し, 結果を考察することにより以下の結論を得た。

1) $N u_{m}$ は $G r^{*} / R e^{* 2}$ をパラメータとし, $P e^{*}$ の関 数として整理できた。低 $P e^{*}$ 領域を除き， $\alpha_{m}$ は 
$G r^{*} / R e^{* 2}$ とともに増大する。

2）流入部境界条件である速度分布は熱伝達に影響す るが，王力条件は計算した範囲では影響がなかった。

3）温度場は $P e^{*} \leqq 1.5$ の低 $P e^{*}$ 領域で十分発達す る。このとき，Num $G r^{*} / R e^{* 2}$ にかかわらず式 (21) で与えられる。

4）境界条件 $U_{1}=1$ のとき， $N u_{m}$ は式（38）で近似 でき, $G r^{*} / R e^{* 2} \rightarrow 0$ とし強制対流時の $N u_{m}$ は式 (39) で近似できた。

$5 ）$ 境界条件 $U_{1}=3 / 2\left(1-4 Y^{2}\right)$ のとき, 強制対流時 の $N u_{m}$ は式 (41) で近似できた。

6) 速度分布が $U=3 / 2\left(1-4 Y^{2}\right)$ で変化しないと仮 定した強制対流時の $N u_{m}$ は式（42）で近似できた。

7) 境界条件 $U_{1}=1$ のとき, $P e^{*}=10^{4}, G r^{*} / R e^{* 2}$ $=0.1 \sim 100$ の值を用い, 馬㴊ら ${ }^{10)}$ の垂直平板の結果と 比較し满足すべき一致をみた。

8) $G r^{*} / R e^{* 2}$ が大のとき, 流れ場は $10<P e^{*}<100$ の中間領域で最も不安定となる。

9) $G r^{*} / R e^{* 2}$ が小のとき, $\alpha_{m}$ は $P e^{*}=10$ 付近で極 大值をもつ。

\section{謝 辞}

本研究にあたり早稲田大学井上宇市教授より御指導と 貴重な御助言を賜わり, 工学院大学中島康孝教授より御 助力を頂いたことに深謝致します。数値解析，関数近似 の吟味，図表の作成などに斉藤章二，加藤義弘，斉藤千 春の諸君の協力を得た。ここに記して謝意を表します。

本数値解析には東京大学大型電算機センターの電算機 システムを利用した。

本研究に昭和 55 年度工学院大学特別研究費(3)の一部 を使用したことを付記する。

註

1）分割数之格子間隔: $\Delta X_{i}, \Delta Y_{j}$

$X$ 方向の格子間隔 $\Delta X_{\text {i }}$ は下記のごとく $\Delta X_{i}$ 群の比を決め

$\sum_{i=1}^{k} \Delta X_{i}=1$

となるようそれぞれの $\Delta X_{i}$ を決定する。

$1 \leqq i \leqq 20: 0.001$

$21 \leqq i \leqq 40: 0.002$

$41 \leqq i \leqq 50: 0.004$

$51 \leqq i \leqq 60: 0.01$

$61 \leqq i \leqq k: 0.02$

$Y$ 方向の格子間隔 $\Delta Y$ は次式より $\Delta Y_{j}$ 群の比を決定する

$$
\Delta Y_{j}=A^{j} \quad A=1 / 1.1
$$

次いで，次式によりそれぞれの $\Delta Y$ ，を調整する。

$$
\sum_{j=1}^{n} \Delta Y_{j}=\frac{1}{2}
$$

分割数は計算精度を確認しながら数回の試行を重かたのち決 定したもので，表一1に本報の場合を示す。

\section{主要記号}

$a:$ 熱拡散率 $\mathrm{m}^{2} / \mathrm{s}$

$b:$ 平行平板の間隔 $\mathrm{m}$

\begin{tabular}{|c|c|c|c|}
\hline $\mathrm{Gr}^{*} / \mathrm{Re}^{\star^{2}}$ & $\mathrm{Pe}^{*}$ & k & $\mathbf{n}$ \\
\hline $0 \leq \mathrm{Gr}^{*} / \mathrm{Re}^{\star^{2}} \leq 20$ & $10^{-1} \leq \mathrm{Pe}^{*} \leq 70$ & 100 & 40 \\
\hline$=$ & $10^{2} \leq \mathrm{Pe}^{*} \leq 2 \times 10^{4}$ & 100 & 60 \\
\hline $\mathrm{Gr}^{*} / \mathrm{Re}^{* 2}=50$ & $10^{-1} \leq \mathrm{Pe}^{*} \leq 10$ & 100 & 40 \\
\hline , & $\mathrm{Pe}^{*}=20$ & 200 & 80 \\
\hline$:$ & $\mathrm{Pe}^{*}=50$ & 200 & 100 \\
\hline 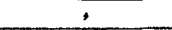 & $P e^{*}=70$ & 251 & 60 \\
\hline 7 & $20^{2} \leq \mathrm{Pe}^{*} \leq 2 \times 10^{4}$ & 100 & 60 \\
\hline
\end{tabular}

Table 1 Subdivision for finite-difference.

$$
\begin{aligned}
& g: \text { 重力加速度 } \mathrm{m} / \mathrm{s}^{2} \\
& h: \text { 平行平板の高さ } \mathrm{m} \\
& p \text { : 平板間の圧力（静圧） } \mathrm{Pa} \\
& t: \text { 温度 }{ }^{\circ} \mathrm{C} \\
& t_{1} \text { : 周囲の空気温度 }{ }^{\circ} \mathrm{C} \\
& u: x \text { 方向速度成分 } \mathrm{m} / \mathrm{s} \\
& \bar{u}_{1} \text { : 平板入口の平均空気速度 } \mathrm{m} / \mathrm{s} \\
& v: y \text { 方向速度成分 } \mathrm{m} / \mathrm{s} \\
& \alpha_{m} \text { : 平均熱伝達率 } \mathrm{W} /\left(\mathrm{m}^{2} \cdot \mathrm{K}\right) \\
& \alpha_{x} \text { : 局所熱伝達率 } \mathrm{W} /\left(\mathrm{m}^{2} \cdot \mathrm{K}\right) \\
& \beta \text { : 空気の体膨張係数 } 1 / \mathrm{K} \\
& \theta_{f}: \text { 温度差 } t_{f}-t_{1} \mathrm{~K} \\
& \lambda \text { : 熱伝導率 } \mathrm{W} /(\mathrm{m} \cdot \mathrm{K}) \\
& \nu \text { : 動粘度 } \mathrm{m}^{2} / \mathrm{s} \\
& \rho: \text { 密度 } \mathrm{kg} / \mathrm{m}^{3}
\end{aligned}
$$

\section{参考文献}

1）水野宏道：垂直加熱平行平板の層流自然対流熱伝達に関 する実験的研究（暖房用放熱器対流伝熱面の基礎的研究 その 1)，日本建築学会論文報告集，Vol. 348，昭和 60 年 2 月, pp. 19-26

2）水野宏道：平板（ダブルパネル）形放熱器の自然対流熱 伝達 (乱流)（輻射・対流形放熱器の放熱特性 第 15 報)， 空気調和・衛生工学会学術講演論文集, 1982 , pp. $333-336$

3) L. N. Tao: On Combined Free and Forced Convection in Channels. Transactions of the ASME, Ser C, Vol. 82, No. 3, 1960, pp. 233-238

4) S. Ostrach : Combined Natural and Forced Convection Laminar Flow and Heat Transfer of Fluids With and Without Heat Sources in Channels with Linearly Varying Wall Temperatures. NACA, T. N. 3141, 1954

5) E. M. Rosen and T. J. Hanratty: Use of BoundaryLayer Theory to Predict the Effect of Heat Transfer on the Laminar-Flow Field in a Vertical Tube with a Constant Temperature Wall. A. I. Ch. E Journal, Vol. 7, No. 1, 1961, pp.112-123

6) B. Zeldin and F.W. Schmidt : Developing Flow with Combined Forced-Free Convection in an Isothermal 
Vertical Tube, Transactions of the ASME, Ser C, Vol. 94, No. 2, 1972, pp. 211-223

7) G. A. Kemeny and E.V. Somers : Combined Free and Forced-Convective Flow in Vertical Circular Tubes -Experiments with Water and Oil, Transactions of the ASME, Ser C, Vol. 84, No.4, 1962, pp.339-346

8) A.A. Szewczyk : Combined Forced and Free-Convection Laminar Flow, Transactions of the ASME, Ser C, Vol. 86, No. 4, 1964, pp. 501-507

9）鶴野省三，永井四郎：層流境界層熱伝達に及ぼす浮力の 影響, 日本機械学会論文集, Vol. 35, No.270, 1969, pp. 379-383

10）馬㴊幾夫，藤掛賢司：垂直加熱平板に沿う低レイノルズ 数の流れにおける熱伝達, 日本機械学会論文集, Vol.27, No. 180, 1961, pp. 1299-1305

11) J. R. Lloyd and E. M. Sparrow : Combined Forced and
Free Convection Flow on Vertical Surfaces. Int. J. Heat Mass Transfer, Vol. 13, pp. 434-438, 1970

12) J.R. Bodoia and J.F. Osterle: The Development of Free Convection Between Heated Vertical Plates. Transactions of the ASME, Ser C, Vol.84, No.1, pp. 40-44, 1962

13) E.M. Sparrow : Analysis of Laminar Forced-Convection Heat Transfer in Entrance Region of Flat Rectangular Ducts. NACA, T. N. 3331, 1954

14) E. Pohlhausen : Der Wärmeaustausch zwischen festen Körpern und Flussigkeiten mit kleiner Reibung und kleiner Wärmeleitung, ZAMM, Bd.1, pp.115-121, 1921

15) R. H. Norris and D. D. Streid : Laminar-Flow Heat Transfer Coefficients for Ducts. Transactions of the ASME. Vol. 62, 1940, pp. 525-533

\section{SYNOPSIS}

UDC : 697.13:697.11

\section{NUMERICAL SOLUTIONS FOR LAMINAR COMBINED FORCED AND FREIE CONVECTION HEAT TRANSFER BETWEEN VERTICAL IIEATED PARALLEL PLATES \\ A fundamental study for convective heat transfer area of space heater : Part 2}

by HIROMICHI MIZUNO, Assist. Prof. of Kogakuin University, Member of A. I. J.

Numerical solutions are presented for laminar combined forced and free convection heat transfer between finite vertical heated parallel plates. Boundary layer equations are transformed into dimensionless form by introducing the dimensionless variables, and it is found that mean Nusselt number $N u_{m}$ is considered to be a function of modified Peclet number $P e^{* *}$ and parameter $G r^{*} / R e^{* 2}$.

A finite difference numerical method is adopted to solve these equations. Paticular attentions are given to heat transfer results, which cover a wide range of modified Peclet number $P e^{*}$ and parameter $G r^{*} / R e^{* 2}$. For combined convection the heat transfer results are related to following equations.

(1) Fully developed temperature field $\left(P e^{*} \leqq 1.5\right)$

$$
N u_{m}=\frac{1}{2} P e^{*}
$$

(2) For $U_{1}=1$ (Uniform) and $P_{1}=0$

$$
N u_{m}=\frac{1}{2} P e^{* x}\left[1-\exp \left\{-\left(\frac{C_{1}}{P e^{* *}}\right)^{C_{2}}\right\}\right]^{C_{3}} \times\left[1-\exp \left(-\frac{C_{4}}{P e^{* *}}\right)\right]^{-0.245}
$$

where, $C_{1}=(4.5+0.012 B)^{\frac{4}{3}}, C_{2}=1-0.002 B, C_{3}=\frac{3}{4}(1-0.002 B)^{-1}$

$$
\begin{aligned}
C_{4}= & \left(\frac{2.25+0.006 B}{0.76+0.106 B^{0.821}\left[1-\exp \left(-\frac{3.37}{B}\right)\right\}^{0.41}}\right)^{\frac{1}{0.245}} \\
B= & G r^{*} / R e^{* 22} \\
& \left(0.1 \leqq P e^{* *} \leqq 2 \times 10^{4}, 0 \leqq G r^{*} / R e^{* 2} \leqq 50\right)
\end{aligned}
$$

